\title{
A Postmodern Cultural Study of Media Manipulation and Capital Market Expansion
}

\author{
Sadia Afrin \\ Department of English \\ Bangabandhu Sheikh Mujibur Rahman Science and Technology University
}

\section{Постмодерно културно изследване на медийната манипулация и капиталовия пазар \\ Сайда Африм}

Департамент по английски език, Университет за наука и технологии Бангабандху Шейх Муджибур Рахман

\section{Author Note}

Sadia Afrin (D) https://orcid.org/0000-0002-5416-417X

Sadia Afrin is assistant professor at Bangabandhu Sheikh Mujibur Rahman Science and Technology University.

The author has no conflict of interest to disclose.

Correspondence concerning this article should be addressed to the Department of English, Bangabandhu Sheikh Mujibur Rahman Science and Technology University, Gopalganj8100, Bangladesh. Email: sadia.du@ bsmrstu.edu.bd

\section{Бележки за автора}

Садия Африн (D) https://orcid.org/0000-0002-5416-417X

Садия Африн е асистент в Депратамент по английски език в Университет за наука и технологии Бангабандху Шейх Муджибур Рахман

Авторът няма конфликт на интереси за разкриване.

Кореспонденцията относно тази статия трябва да бъде адресирана до адреса на университета Gopalganj-8100, Bangladesh. E-mail: sadia.du@bsmrstu.edu.bd 


\begin{abstract}
Media manipulation is rampant in the present postmodern culture since people are constantly monitored by screens due to the advancement of technology. In the postmodern world, the media have become an inseparable part of everyday life, where there is hardly any scope to spend a single moment without the screen and media. Thus, the current researcher got the impetus to unravel the media's simulated world, which uses images, advertisements, and signs to expand global capitalism. The objective of the study is to explore inquisitively the power and influence of the media and the way these are used to manipulate people. This is a qualitative study that delves into media politics and media economy in an investigative way to uncover the covert targets of the media. The study's major finding is that the media play a vital role in attracting consumers and expanding world commercialism in today's globalized world. Several modern and postmodern writings were extensively studied to scrutinize the manifold facets of media manipulation through different presentations of print and visual formats.
\end{abstract}

Keywords: media, sign, capitalism, simulation, postmodernism

\title{
Резюме
}

Медийната манипулация е навсякъде в настоящата постмодерна култура, тъй като поради напредъка на технологиите, хората са постоянно пред екрана. В постмодерния свят медиите се превърнаха в неразделна част от ежедневието, в което едва ли има възможност да се прекара един момент без медиите. В резултат на това, съвременните изследователи получават тласьк да разгадаят симулирания свят, създаден от медиите. Целта на изследването е да разкрие силата и влиянието на медиите и манипулативната им роля. Чрез качествено изследване се проучва медийната политика и икономика, за да се открои прикритата цел на медиите. Бяха задълбочено проучени модерни и постмодерни презентации на медийни манипулации, Основната констатация на статията е, че медиите играят жизненоважна роля за привличането на потребителите, както и за разширяването на световния комерсиализъм в глобализирания свят.

Ключови думи: медии, знаци, капитализъм, симулация, постмодернизъм

\author{
ARTICLE INFO: \\ Original Article \\ Received: 26, 08.2021 \\ Revised: 30, 09.2021 \\ Accepted: 14, 11.2021
}




\section{A Postmodern Cultural Study of Media Manipulation and Capital Market Expansion}

Media manipulation breaks the boundary between perception and reality, where the differences between real, unreal and hyper-real become indistinguishable. Media have a significant impact on people's thought-processes and decision-making about products through different ways of presentation. Advertisers purchase public attention by paying the media to promote their products. Therefore, advertisements are the root source of media exhibitions (Media Studies 101, 2018). Regardless of their geographical locations, educational qualifications, and economic backgrounds, people are becoming prey to the media and screen. Therefore, people are always under the influence of media manipulation, either consciously, unconsciously, or subconsciously. However, advertising is a powerful media tool for gaining public attention to something, particularly for products and services. In addition to this, business possessors, company owners, and super shop holders who wish to sell, popularize, and publicize their products have connections with the media as they pay for media coverage to have their commodities displayed on television breaks, social media posts as well as in newspapers and magazines. Baudrillard (1993) has mentioned the postmodern society as a 'simulated' and 'hyperreal' world, in which the media and technology control everything including human emotions and rationality. For the benefit of capitalism, the media manipulate people's feelings through the use of images and presentations (Afrin and Muniruzzaman, 2020). Moreover, different organizations and groups increasingly use the media to advertise their work and circulate their messages. It should be noted that in advertisements, there are always some messages, either in inscribed words or through visual depiction and background sound.

Baudrillard (1993) and Jameson (1991) have explained how the capital market manipulates the media to expand marketing strategy and boost the market value of various products. Mulvey (1989) has discussed the function of visual pleasure in bolstering the viewers of any film through erotic demonstrations of women since women are presented as a source of attraction and erotic pleasure for the audience. Advertisement corporations also employ the policy of unveiling displays of women in different advertisements to increase product value. To support the argument of this article, Baudrillard's concept of simulation, simulacra, and hyperrealism (1993), Jameson's idea of late capitalism (1991), Barthes' (1977) writings on the 'Rhetoric of the Image', Saussure's (1916) terms of signifier and signified, and Mulvey's concept 
of visual pleasure (1989) have been used. Several researchers have been noticed working on the topic of the function of the media. Some researchers are interested in product color and flavor, while others are interested in health concerns, advertising targets, and the function of creative media in circulating advertisements. Therefore, the current study highlights the concealed manipulation of consumers in postmodern culture and society through media advertisements and super shops. Thus, the main focus of the paper is on unforced media exploitation to enhance the capital market arena, which targets consumers' attention.

The ultimate target of the advertisements is to sell things or raise public awareness about specific products (Alcantud-Diaz, 2011). Her major focus is on the subliminal seduction of teenagers through media exploitation. Advertisements play an important role in attracting the psychology of viewers, and creative media may also be used to manipulate the audience through a technical presentation. Lazard et al. (2020) have claimed that photo manipulation often persuades consumers about personal care products. Moreover, consumers are continuously being influenced by the advertisement-making and distribution processes through social media. Khurram (2018) has asserted that there are two common techniques of manipulative advertisinglinguistic manipulation and visual manipulation. He also discussed the flavors, packaging tactics, colors, and sound effects used in food product advertising, all of which contribute to attracting consumers.

Caitlin et al. (2020) have investigated the negative impacts of beauty and body care products advertised via digital images on human health. The research emphasized their concern over colorism, which threatens adolescent health worldwide and puts much emphasis on digital manipulation. Images and advertisements are occasionally used as sources of knowledge and discourse. Images now create communication and knowledge by presenting several advertisements on television (Roy, 2020). Moreover, media advertisements raise the necessity for a particular product among the viewers. The media and television are vehicles for disseminating messages to the viewers. Laskar (2015) has worked on Indian advertisements, in which he explained how advertisements use people's sentiments to gain popularity. He asserted that India is a multicultural country, and advertisements, TV serials, reality shows, and other forms of media mislead viewers by creating cultural, religious, domestic, ideological, patriarchal, and emotional narratives and discourses. 
Research Questions: The research questions are: 1. How do the media manipulate people through multifarious presentations? 2. What is the role of advertisements in media manipulation? 3. How does the capital market use media to expand its dimensions?

\section{Methods and Approaches}

The nature of the research is descriptive and content-based. To analyze the topic of this article, theories of postmodernism and cultural studies were explored. As prospective sources of information and analysis, Pramod K. Nayar's (2011) An Introduction to Cultural Studies and Christopher Butler's (2002) Postmodernism: A Very Short Introduction were considered. Most of the supplementary data and information came from printed books, articles published in journals, internet sources, digital images, advertisements, and videos. The inscribed words on several images collected from the internet were studied to show how media manipulation works to control and brainwash the human psyche.

\section{World of Simulation}

The function of the media and capitalism has been elucidated by the postmodern thinker and theorist Jean Baudrillard. The capital market expands its boundaries through media where product value is less important than images and signifiers. Selden et al. (2005) emphasizes Baudrillard's idea of consumption, overproduction, signifiers, and signified in modern capitalist society. Media presentations that manipulate viewers who are unable to distinguish between "surface and depth or the apparent and the real," according to Baudrillard, are manipulative (pp. 200-201). Baudrillard (1993) focuses on the surface and reality, observing how the media manipulate everyone by creating fake necessities among people, where there is no reality and only simulation exists. According to Media Studies 101 (2018):

The uses and gratifications paradigm views audiences as active seekers of media that best fulfill their needs, or that reinforces their existing beliefs and interests (p. 57).

People's rationality and deliberation are grabbed by media presentations because they cannot differentiate between the original and the fake. Only 'floating images' and 'endless repetition of images' are found in this postmodern cultural society through photocopy, digital copy, and media technology. The distinction between real and unreal/fake, original and copy, genuine and illusion, superficiality and depth has broken down in the era of reproduction. What people now get is a culture of 'simulation' and 'hyperreality' where there is hardly any originality (Baudrillard, 1993). Reality is built through the images presented by the media, so there is no 
longer any existence of rational thought. Moreover, people may not always realize what they actually need, but the media instill a sense of urgency in them. Therefore, the question of 'where does reality lie?'- is a significant search in postmodern society. Everywhere there is a simulation, the reality is lost since the media promote the capital market by producing this simulated world through its continuous representation. Representation employs a number of 'signs' that expose metaphorical and symbolic meaning, and consumers perceive meanings by observing those signs. Representation can be "an image, a word, a sound or a concept" and it uses "these 'signs' to generate meaning" (Nayar, 2011, p. 21). Through different processes of representation, the world has now turned into a simulated world where behind each image, every advertisement, there is a discourse, a purpose of manipulation. The manipulation is carried out either through the use of languages or by the display of an image (sign) on a screen. The following figure exposes some manipulative words written on beauty products that are frequently featured in media advertisements:

\section{Figure 1}

The Language Written on Beauty Products Advertisements

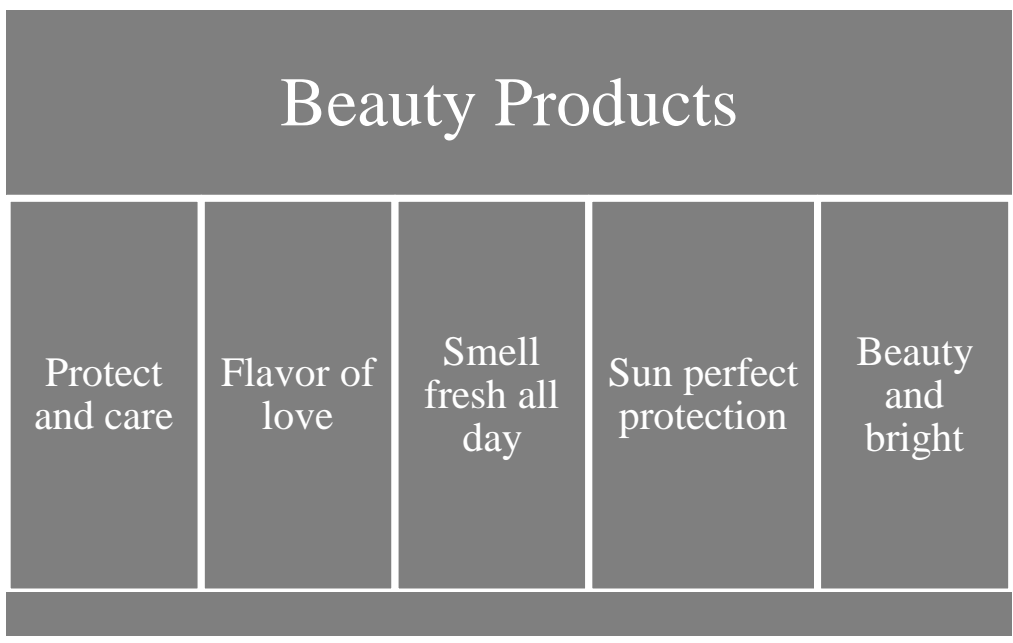

These are the deceptive words that may be found in numerous personal care product advertisements. The media uses this language game to create discourse behind every advertisement. Images and advertisements can have different layers of meanings, as has been shown by Barthes (1977) in 'Rhetoric of the Image.' The words inscribed on several advertisements are enough to attract the attention of the audience and consumers. For example, 
in most body lotion, face wash, and moisturizing cream advertisements, a white body or a white, spotless face is depicted, and in reality, everyone has a desire for white skin. Advertisements are to blame for instilling the feeling of racism in people. The idea conveyed by these advertisements is that by utilizing those products, skin can be attractive and protected from sunlight. Consumers are unaware of the ingredients and are attracted to beauty products because of the eye-catching portrayal of beautiful skin. Caitlin et al. (2019) have conducted a study on the media depiction of beauty products and their health implications, in which they have attempted to show the detrimental effects of certain beauty and personal care products. The media create an illusion regarding light skin, claiming that light skin 'equals beauty, success, and social mobility' (p. 9). Consumers have been enslaved by the media in such a way that they have lost touch with reality and actual necessity. The ultimate success goes to the capital market, which is now able to promote its products using the media. The coded messages in these beauty product advertisements can be skin that feels good, pimple-free healthy skin, fight pollution, etc. and these words contribute to gaining public attention. Similarly, words like an irresistible offer, skin whitening cream, pore refining solution, spotless glowing skin, and so on are used to draw the attention of viewers.

The confusion between reality and illusion has been created, and the word 'real' is defined in terms of media circulation. It is the 'image-creating' postmodern communication technologies, particularly television, which, according to Baudrillard, "stimulate this proliferation of selfgenerating images across the postmodern surface" through their repeated presentation (Selden et al., 2005, p. 201). Objects in a consumer society in contemporary postmodern culture are not merely bought and consumed; they also signify a mission for status rather than just satisfying a need. Consumers consume images because they provide them with meaning and necessity.

\section{Function of Advertisements}

Saussure (1916) has mentioned the terms sign, signifier, and signified, where the concept is signified, the sound image is the signifier, and "the bond between the signifier and the signified is arbitrary" (Bally et al., 2015, p. 67). These terms can be applied to explain media manipulation as follows: the images presented on the screen are signifiers, and the messages provided through those images are signifieds, where the audiences are manipulated with both signifiers and signifieds. The representation of product consumption through advertisements as well as how consumers consume advertisements constitutes the portrayal of 'consumer culture' 
in the mass media (Nayar, 2011). Advertisements and media presentations direct people's thinking and point them the direction- where to go, what to purchase, and what the necessity is. According to a textbook of the Media Texthack Team, by highlighting and presenting certain events and goods repeatedly, the media generate a sense of "urgency and desire for those things and products, though it is not always a vivid reflection of reality" (Media Studies 101, 2018, p. 54). The media manipulate the audience, viewers, and consumers through various kinds of advertisements and multiple ways of visual presentation. Consumers become attracted to viewing either the coded words in the images and visual presentation or the way in which such presentations are made. Nayar (2011) has stated that "advertisements frequently showcase identity" and the words 'be yourself', 'develop your self-esteem' are often coded to persuade consumers that consuming specific products is essential to their identity (p. 125). Products and commodities are now related to people's identity, fashion, lifestyle, and respect. People's tastes in fashion and style are represented by the items they use and the things they buy, and the capital market takes advantage of this commodity fetishism. With the help of the media, the capital market now dominates human emotions, necessities, ideas, beliefs, thoughts, and almost everything related to a person's life.

Besides, the media manipulate the audience and consumers by using the face value of renowned people. The widespread opinion among viewers is that as the popular figures appear on screen with the advertisements for those products, those are unquestionably the best products (Afrin and Muniruzzaman, 2020). Thus, the Vivo mobile phone advertisement has been featured first by Ranveer Singh and then by Aamir Khan both are well-known Bollywood male celebrities. People easily become manipulated when they see their favorite actors/actresses on the screen with advertisements for several products, and this is where the value of representational practices lies. Most of the time, people are unaware that they are not always in control of their lives, choices, and consumption; they are sometimes the subjects of ideological control, hegemony, and subliminal seduction through media representation.

The capital market wants to accelerate the market value of its products and it requires the ladder of advertisement to accomplish so. The media help a lot in expanding the capital market by drawing the attention of consumers and viewers with its presentation. This presentation can be through advertisements, cinemas, dramas, songs, talk shows, reality shows, TV serials, etc. For example, in the film Chennai Express (2013), Shahrukh Khan intentionally highlights his 
mobile phone in a sequence. This scene features an advertisement for the Nokia Lumia 920 mobile phone model. Thus, by using the fame of the Indian superstar Shahrukh Khan, known as 'King Khan' in the Bollywood world, a mobile phone company, namely Nokia, promotes its products. As Shahrukh Khan is there with that phone, people intend to purchase this new model of Nokia Lumia.

Although media culture has its own point of view and set of ideas, it offers suggestions instead of explicit assertions. There are several marketing strategies for promoting products like soft drinks, food, accessories, and outfits. Still, it might be misleading if someone always considers the display of the consumption of products by a celebrity in a filmy style or the use of branded clothing as an overt branding strategy. It has become a standard practice of the media to showcase stars in branded clothing to convey to the audience that their attractiveness is inherent. This is how the media play with human emotions, and there are multiple exhibition styles for different people. For instance, the younger generation's choices, tastes, and consumption patterns are important to the culture of mobile phones, laptops, tablets, and other electronic devices, and nowadays, updated technological devices are the icons of lifestyle for young people (Wilska, 2003). This is how the media manipulate consumers, and the presentation style varies depending on the age, taste, and needs of the audience. Young people contribute a lot to promoting the fame of any product or capital market since young people are much more interested in current trends, dress codes, fashion, style, and so on. So, through different advertisements, the media try to gain young people's attention. Similarly, advertisements for cosmetics, accessories, mobile phones, clothes, and other items are made following the tastes and demands of girls, women, men, and people of different ages.

\section{The Capitalist Mindset of Corporate Culture and Film Media}

The only thing that matters to the corporate culture is profit, and in order to make profit, it employs numerous marketing strategies. Besides, the economic system and the capital market are complementary in media circulation. According to a textbook published in Victoria, B.C:

The financial situation is also of critical relevance to the ideological context of media

content. As the media is funded by commercial (primarily corporate) organizations, the products produced by this system are highly unlikely to be pointedly critical of corporate capitalism and consumerism (Media Studies 101, 2018, p. 69). 
The media's content is not always polished and accomplished, but is sometimes full of negative components as well. The capital market occasionally attracts viewers through movies, songs, and pornographic presentations, with the younger generation as their primary aim, since these people are easily hegemonized by media fashion and presentation. Thus, they become addicted to pornography, banned films, erotic literature, and other forms of erotica. Young people are much more fascinated by the erotic music and songs shown on channels such as MTV. Nayar (2011) has highlighted an important point about the circulation and worldwide popularity of Hollywood films. The way Hollywood films have been circulated globally and celebrated by the poorer nations of Asia and Africa is a matter of concern and deep thought.

Mulvey (1989) analyzes the dark side of the media and the portrayal of women in narrative cinema. Film industries produce films with the goal of making money by increasing the popularity of the films among audiences. Producers and directors represent women on screen as commodities in order to earn fame and popularity. Mulvey (1989), a feminist writer, specializes in the psychoanalysis of women portrayed in the media as objects of male gaze, erotic and voyeuristic pleasure. There are three distinct looks associated with film production: the camera as it records the 'pro-filmic event,' the audience as they watch the production, and the characters on the screen (Mulvey, 1989, p. 26). As a result, women become victims of the 'male gaze' in three different ways: first, in the eye of the director and producer as they view through the lens of the camera; second, by male audiences; and third, by male characters on screen. The erotic presentation of female characters both in cinema and advertisements appears on the screen since audiences digest those images. The presentation and representation of women in the media reveals the dark side of expanding capitalism. In commercial cinemas, to make the films blockbusters, female characters are presented and represented in multiple erotic ways to grab the public's attention. In advertisements, products like body lotions, body sprays, different cans, and bars are presented in female body shapes (female waist shapes) to attract viewers. There are trailers, posters, and magazines for upcoming films, and in these posters, newspaper articles, or magazines, erotic images of women are displayed. The media have the power to mesmerize and control the audience through the erotic and stylistic representation of women. The hidden purpose of the film industry is to gain profit by making blockbusters, and the aesthetic values of the films are merely focused. 
In postmodern culture, corporate society primarily contemplates the commodification of everything. Commodification is defined as the identification of human beings, women, friendship, and knowledge as commodities, which is an inhuman money-making strategy in the globalized world of capitalism. Concerning other animal species, human beings and all their endeavors have an exchange value. It is a systematized transformation in which the emotional relationship has an exchange value like buying and selling. In the corporate world, the identity of the laborer gets covert in the commercialization process, and the laborers get a reduced wage for their labor. Similarly, in the corporate job market like airlines and shopping malls, beautiful women are employed as their physical beauty has an exchange value. The global capital market has accomplished this by virtue of powerful media that define and redefine the concepts of beauty, taste, elegance, luxury, etc.

\section{Consumption Value of the Products}

The capital market and consumer market depend on the people who buy and consume the products. Consumers or buyers have a great contribution to expanding the market value of a product since the products of consumption are the objects advertised by the media, sold by the company, and purchased and consumed by the consumers. The market uses the policy of advertising, and people related to the market policy advertise those products by using the media. Therefore, it is apparent that both the media and the capital market have enormous contributions in manipulating consumers' perceptions of any given product. Commodities have special prominence in social relations, and the process in which commodities obtain importance in society is regarded as consumption. The utilization of some objects creates meaning, and this meaning-making process is acknowledged as consumption. In this process, commodities are transformed into signs referring to values, social standing, efficiency, tradition, and so on, and tangible objects are often used to represent those signs (Nayar, 2011).

In addition to this, rhetoric plays a vital role in convincing consumers since "in advertising, the signification of the image is undoubtedly intentional..." (Barthes, 1977, p. 32). To emphasize the importance of rhetoric or other meanings and messages conveyed by any image, Barthes used the example of a panzani pasta advertisement in which linguistic, connoted, denoted, coded, and non-coded messages get focused (p. 33). People choose and buy certain products not just in terms of their design and utility value, but also in terms of the packaging and rhetoric that make them attractive, essential, and significant. The media create rhetoric through 
several advertisements on the screen. Advertisements convey several messages, either connotative or denotative, in which sometimes the meaning is clear with language, and sometimes there is a hidden and metaphorical meaning. The following figure depicts several manipulative messages conveyed by household product advertisements:

\section{Figure 2}

Rhetoric of Household Product Advertisements

\section{TV and REFRIGERATOR}

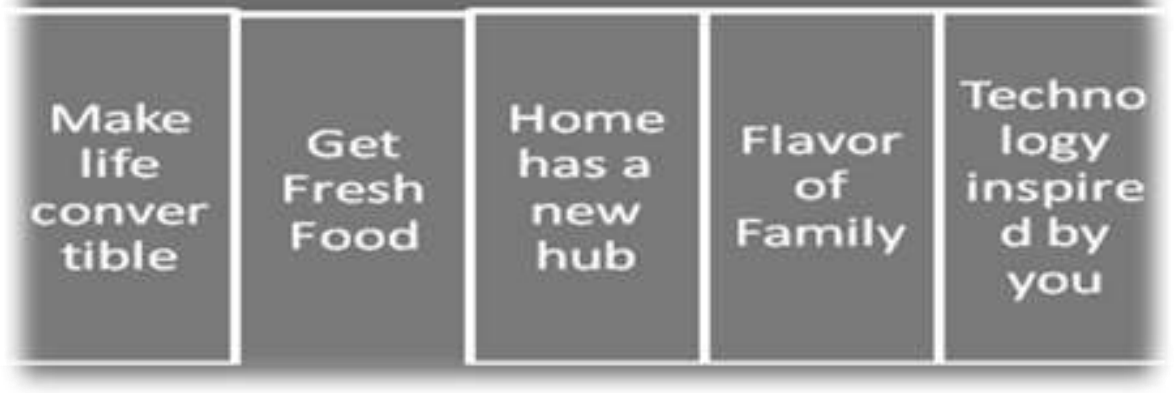

The words mentioned above have been inscribed on the advertisements for televisions and refrigerators. Since people are hankering after a happy family, tasty and fresh food, the advertisements use these kinds of words to attract them.

The setting and presentation of the advertisement are done in such a way that they easily touch the hearts of the viewers and encourage them to buy the products. For example, the advertisements for refrigerators symbolize fresh and tasty foods for all family members through the coded message- it's the family hub, tasty food for all, full freshness, more space inside, more stylish and spacious, and so on. Besides, the advertisement on television indicates a happy and harmonious family where everyone enjoys spending time together. This is how manipulation works through visual presentation.

To convince consumers about the usefulness of products, media advertisements very consciously provide some messages, either literal or metaphoric. For example- a sign of good taste is inscribed in the Coca-Cola advertisement, $100 \%$ better germ protection is inscribed in the Lifebuoy soap advertisement, and the taste is the difference has been coded in the advertisement for Indomie noodles. The capital market wants to accelerate the market value of products, and the method of doing so is through advertising with coded or symbolic messages. 
Words like organic food, fresh food, and natural food are sometimes used to promote the popularity of products (Afrin \& Muniruzzaman, 2020). These visible and invisible messages (connotative and denotative) easily attract the attention of viewers and consumers, and this is the policy of the capital market to increase the market value of products. Food products are more popular and diverse worldwide, and in media advertisements, food products are shown in different ways to familiarize people worldwide. Food culture has become the most popular and significant tool of globalization and global capitalism. At present, Chinese, Italian, French, and American foods are available in other countries of the world, demonstrating the triumph of capitalism. Italian pasta and pizza, French fries, German's burger, Chinese noodles, Australian cookies, Thailand's soup, Japanese cuisine and American fast foods are now available in countries like India and Bangladesh, and other parts of the world.

Packaging and color symbolism are sometimes used to gain the attention of consumers. The language of packaging also indicates possible consumers, utility values, and market values. In most cases, brands also create market value for the product since the brand indicates the identity of the product as well as the identity of the manufacturer company (Afrin \& Muniruzzaman, 2020). Apple (a popular laptop and mobile phone brand), Coca-cola (a popular soft drinks brand), Toyota and Mercedes (popular vehicle brands), Samsung (a popular electronic products brand), and so on are some examples of world-famous brands. Brand image can be a huge factor for companies, and their success and brands influence consumers to buy certain products.

Moreover, branding aids in the promotion of a company's product's fame and acceptance among consumers. In Bangladesh, for example, Aarong is a popular brand that sells clothes, cosmetics, handicrafts, showpieces, and other handmade necessary accessories. The working class of people like weavers, blacksmiths, and potters make those products, but they do not get the proper payment for their labor. Instead, just because of a logo, Aarong sells those products at a high price. Thus, human beings today live in "a system of consumption where the act of buying a product is as abstract as how the products are made in the first place" (Lane, 2003, p. 74). The producers are deprived of the price, but the capital market obtains high prices with a logo that has national brand value, and people also buy those products at high prices because of the brand value. It is just a simple example of the Bangladeshi market; capitalism expands in this way all around the world. 


\section{Consumer Manipulation}

The capital market started to flourish with industrialization, and the industrialized countries participated in its expansion. After WWII, there was no way of direct colonialism; economic manipulation was the most effective means to hegemonize people's choices and expand the global market economy. According to Ewen, the development of capitalist production demanded "the construction of new markets and the 'education' of publics to become consumers through advertising and other media" (Qt. in Featherstone, 2007, p. 14). The rhetoric of advertisements can sometimes be very effective in manipulating audiences. The following figure depicts some coded messages written on food products that are highlighted repeatedly by media advertisements:

\section{Figure 3}

Coded Messages Provided through food Product Advertisements

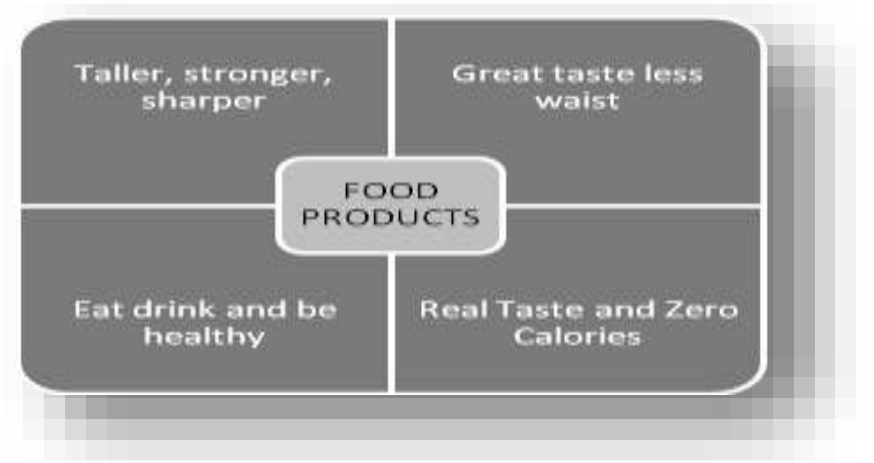

These messages are inscribed on the packets and cans of food products to make the products more attractive to the viewers. Human beings always desire to make life easy and comfortable, and they are always fascinated by the prospect of getting new things such as accessories, beauty tools, food products, and so on. Advertisements play a prominent role in influencing human choice and rationality through their display and presentation. Ewen asserts:

In particular, advertising can exploit this and attach images of romance, exotica, desire, beauty, fulfillment, communality, scientific progress, and the good life to mundane consumer goods such as soap, washing machines, motor cars, and alcoholic drinks (Qt. in Featherstone 2007, p. 14).

In an era of overproduction and multiple productions, people have become puzzled by the abundance of lots of similar products on the market. In the capital market, there is constantly a 
rat race to increase product appeal among consumers since only the greatest will survive. Consumers get confused about the utility value of the products amid extreme signs and images. The commercials want to check the consumers' response to products being presented on the market and how much they are manipulated to grab and buy them. To expand the market, it is important to screen products and shops and test consumer reactions (Lane, 2003, p. 42). Thus, the media function to circulate messages through images by presenting the utility value of certain products.

Shopping malls play a vital role in drawing attention and increasing consumer demand. The key role of market policy is to catch consumers' attention through product arrangement and presentation, which commercials often achieve through shopping malls. A mall is a place where buyers can get almost everything they need, and these malls are advertised in such a way that viewers become attracted. The supermarket and shopping malls expose a complete picture of the commodification of things. A super shop or mall raises appeal and desire for certain products since the mall displays products or commodities for maximum visual appeal. In malls, the products are displayed beautifully, and the decoration of the products stimulates a desire among purchasers. The mall is also a "postmodern secular space" that is free from the divisions of religion, caste, creed, and class; there is only one class, that of purchasers and consumers (Nayar, 2011). People's consumption, fashion, and style are influenced by media and television advertising. The prominent postmodern thinker, Baudrillard (1993) has focused on the terms 'hypermarket' and 'technology'. The media repeatedly presents the setting and picture of a shopping mall appealingly to viewers, and consumers become manipulated, boosting the consumption value of the products. Television screens raise desire among people by deliberately and continuously showing the setting and picture of the hypermarket as a place of comfort and dream. Audiences and consumers are tested through the representation of the hypermarket on the screen.

The setting of the market and the projection of the commodities or products have a significant impact on the feelings of shoppers and consumers in hypermarkets. Commodities are no longer commodities in the eyes of consumers; rather, they are hyper commodities. People are motivated to visit the hypermarket through media advertisements; people's desire is the byproduct of the media presentation. People buy products not by seeing the utility value of those products but by being influenced by the projection and presentation of the media as well as the 
setting of the market. So, the media generate utility value, while also expanding the capital market.

\section{Postmodernism and Late Capitalism}

The expansion of the capital market was observed after industrialization, and late capitalism is currently observed in this postmodern culture. The rise of late capitalism and consumer capitalism is responsible for the emergence of postmodernism (Jameson, 1985). Now, the logic of global capitalism is that people are not only citizens of a particular nation or country; rather, they are citizens of the whole universe. Being citizens of the entire world, people must contribute to the expansion and development of the global capital market and the global economy. At present, multiple signs and deceptive discourses influence people's consumption and utilization of products. Butler (2002) states:

We are simply enclosed in a media-dominated world of signs, villainously generated by capitalism to synthesize our desires, which only really refer to one another within an entrapping chain of ideas (p. 114).

Media anchorage has an impact on everyone's everyday activities. Nowadays, people are surrounded by a "sensory overload of images" in newspapers, television, the internet, social media, and other places that promote the market value of products (p. 117). People's faces are now covered with the media's exaggerated narratives and marketing strategies. In this media generated postmodern era, marketing "takes precedence over production" (p. 115). The postmodern theorist Baudrillard (1993) supports the idea of the overproduction of images where reality has been lost:

The cool universe of digitality absorbs the universe of metaphor and metonymy. The simulation principle dominates the reality principle as well as the pleasure principle (p. 458).

The world is becoming increasingly digital as a result of technological advancement which is dictated by the simulation principle, which promotes capitalism. Baudrillard called this media-dominated capital market "a generalized brothel of capital, a brothel not for prostitution, but substitution and commutation" (p. 440). In the media, there are instances when a double standard has been presented. Smoking and drinking, for example, are harmful to one's health. This haphazardness is portrayed by the media but it also displays a lustrous setting in which 
heroic personalities smoke and drink as part of a contemporary, sophisticated lifestyle. As a result, media generates a world that is dominated by surface reality rather than deep reality. This is the postmodern culture of depthlessness, as Jameson (1991) has pointed out. Jameson observed the postmodern world and culture as the culture of consumer society, the post World War II stage of late capitalism. The overwhelming exposition of the visual media regulates people's aspirations and demands in this superficial culture. Featherstone (2007) has stated:

The autonomy of the signifier, through, for example, the manipulation of signs in the media and advertising, means that signs can float free from objects and are available for use in a multiplicity of associative relations" (p. 15).

People are unable to follow their instincts due to the signs and simulations. The inherent logic of consumer-capitalist society leads us towards a postmodern culture in which consumers' false desires and 'floating images' lead to multinational capitalism (Jameson, 1991). In the postmodern era, social media have expanded significantly, reaching all corners of the world, with business corporations taking advantage of this expansion. Corporations are interested in online, TV advertising, and branded online content because it allows them to deceive users, as companies can increase their reach through social media (Fuchs, 2019). He has presented Herman and Chomsky's argument that advertisements are a major source of income for media outlets that display advertisements through spectacles (p. 72). The majority of people are now engrossed in the realm of social media which allow them to readily view promotional advertisements from multiple companies. Besides, the power of corporations has increased as a result of "native advertising and branded content," which enables the capital market to flourish (p. 86). Thus, in this age of advanced technology, capitalism takes advantage of social media platforms, which have become popular communication and distribution platforms. Ewen explains that everywhere there are signs, images, and simulations that contribute to hiding the real meanings, and thus the consumers are attracted to the illusion of visual projection, losing their rationality and thought (Qt. in Featherstone, 2007). The postmodern world has been transformed into a completely simulated world in which everything is reproduced and represented repeatedly, leading to a world of late capitalism. According to Prodnik (2012), nowadays, audiences are "instrumentalized" by capital, meaning that audiences' ideas, beliefs, and thoughts are commodified through visual presentation (p. 289). Audiences are the sole target of the media, as they are an integral part of the expansion of capitalism in postmodern culture. 


\section{Conclusion}

This paper attempted to clarify the notion of media manipulation and the expansion of the capital market in the media presentation. In postmodern societies, the media and advertisements hinder people's rationality by grabbing mass audiences' thoughts. The main weapon of the capital market is the manipulation of consumers, and the media contribute substantially to this process. The development of technology also increases media presentation, which serves as a critical component in reaching individuals of all socioeconomic strata. Social media, radio, television, etc. in a word, all kinds of screens, printed, audible as well as visible media are now available in every corner of the world. There are no boundaries to reaching media display, such as to orient or occident, rich or poor, literate or illiterate, black or white, male or female, young or adult. Thus, the capital market advertises products and raises necessity among people through media presentation; sometimes the necessity is a fabricated necessity or simply the impact of the presented sign or image. The messages provided by media advertisements often influence viewers' desires and decisions to buy a certain product. The capital market today circulates messages through media by creating discourse and narratives for its viewers, who grab those without judgment. As a consequence, the media brainwash audiences to buy and consume specific products, and consumers continue to contribute to the expansion of the capital market by consuming certain products, influenced by media circulation.

\section{References}

Afrin, S. \& Muniruzzaman, S. M. (2020). Image becomes language: Media and capitalism in Barthes' rhetoric of the image. Journal of Literary Studies, 2(2), 1-11, doi: $10.5281 /$ zenodo.3612767

Alcantud-Diaz, M. (2011). Manipulation of teenagers through advertising: a critical discourse approach. Revista de Lingüística y Lenguas Aplicadas. 6, 25-38, 10.4995/rlyla.2011.879

Bally, C. et al. (Ed.). (2015). Course in general linguistics Ferdinand de Saussure. (W. Baskin, Trans.), McGraw-Hill Book Company.

Barthes, R. (1977). The rhetoric of the image. Image, Music, Text. Hill and Wang. Baudrillard, J. (1993). From symbolic exchange and death. In L. E. Cahoone, (Ed.), From Modernism to Postmodernism: An Anthology. Blackwell Publishers, 437-460. 
Butler, C. (2002). Postmodernism: A very short introduction. Oxford University Press.

Caitlin, M. et al. (2019). Digital manipulation of images of models' appearance in advertising: strategies for action through law and corporate social responsibility incentives to protect public health. American Journal of Law \& Medicine, 45, 7-31. doi:

$10.1177 / 0098858819849990$

Chennai Express. [Film]. (2013). Directed by Rohit Shetty, Red Chillies Entertainment, UTV Motion Pictures.

Featherstone, M. (2007). Consumer Culture and Postmodernism. SAGE Publications Limited. Fuchs, C. (2019). Propaganda 2.0: Herman and Chomsky's propaganda model in the age of the Internet, Big Data, and Social Media. In Pedro-Carañana Joan, Broudy Daniel and Klaehn Jeffery (Eds.), The Propaganda Model Theory: Filtering Perception and Awareness. University of Westminster Press, 71-92.

Jameson, F. (1985). Postmodernism and Consumer Society. Postmodern Culture, 115(11), 111-125.

Jameson, F. (1991). From the cultural logic of late capitalism. In L. E. Cahoone, (Ed.), From Modernism to Postmodernism: An Anthology. Blackwell Publishers, 556-572.

Khurram, M. (2018). Impacts of manipulative advertising on the consumer perceptions of ready-to-eat foods market in London. GRIN, www.grin.com/document/489410

Lane, R. J. (2003). Jean Baudrillard. Routledge.

Laskar, K. A. (2015). Recognizing the politics of visual imagery through transplanted traditions in Indian television soap operas. Media Watch, 6(2), 193-199. doi:10.15655/mw/2015/v6i2/65664

Lazard, A. J. \& Bock, M. A. \& Mackert, M. S. (2020). Impact of photo manipulation and visual literacy on consumers' responses to persuasive communication. Journal of Visual Literacy, 39(2), 90-110. doi:10.1080/1051144X.2020.1737907

Media Studies 101. (2018). A creative commons textbook. Media Texthack Team.

Mulvey, L. (1989). Visual pleasure and narrative cinema. Visual and Other Pleasures: Language, Discourse, Society. Palgrave Macmillan.

Nayar, P. K. (2011). An introduction to cultural studies. Viva Books Private Limited. 
Prodnik, J. (2012). A note on the ongoing processes of commodification: from the audience commodity to the social factory. TripleC Journal, 10(2), 274-301.

Roy, D. (2020). Ideology, age of the image, and television advertising in India. Asiatic, 14(1), 286-296.

Selden, R. et al. (2005). Postmodernist theories. A reader's guide to contemporary literary theory. Pearson Education Limited.

Wilska, T. A. (2003). Mobile phone use as part of young people's consumption styles. Journal of Consumer Policy, 26(4), 442-464. 